\title{
Performance of the Indian Banking Sector - An Empirical Examination
}

\author{
Ainsley Granville Andre Jorge Bernard, Brahma Edwin Barreto, Rodney D'Silva
}

\begin{abstract}
A fundamental role of the banking sector in India is observed with regards to the social as well as economic development of the country. Sustainable economic growth can be achieved only if a healthy and robust banking system exists within the country. The banking sector's performance is a closer link to the economy than perchance that of other segments. After nationalization of banks in 1969, a remarkable level of prominence as well as expansion of nationalized and public sector banks were witnessed and today the banking sector in India is well regulated and adequately capitalized. In recent years, there has also been tremendous growth and expansion in private banks in India. The current research aims at mapping the performance and financial health of banks based on basic parameters like income, expenditure, profit, loans, deposits and interest. Ratio analysis is used to scrutinize performance of the banks considered for the purpose of this study. T-Test has been used to establish the existence of any noteworthy difference between financial ratios of the considered Indian private and public sector banks.
\end{abstract}

Keywords: Performance, Financial Ratios, Public Sector Banks, Private Sector Banks

\section{INTRODUCTION}

In India, the banking sector is considered as the central financial pillar that occupies a key position in the functioning of the country's economy. Banks have undoubtedly played a pivotal role in the country's socioeconomic progress especially post independence. The banking sector is an undeniable element in the progress of the Indian economy. Since banks were nationalized in 1969, the public sector banks have attained prominence and seen tremendous expansion in India. Over the preceding decade, the Indian banking system has gone through a complete transformation. Reform measures taken in the Indian economy are principally designed to improve the functioning of banking since it is the key segment of the financial sector of the country. Prominent positive externalities result from an efficient system of banking and these further increases the efficiency of economic transactions in general.

\section{LITERATURE REVIEW}

Mumupilly (1980) scrutinized the outlay and how profitable commercial banks are in India. The study

Revised Manuscript Received on 14 August, 2019.

Ainsley Granville Andre Jorge Bernard, Assistant Professor, Department of Commerce, V.V.M's Shree Damodar College of Commerce \& Economics, College in Margao, Goa, India.(Email: ainsley.bern@gmail.com )

Dr. Brahma Edwin Barreto, Associate Professor, Department of Commerce, V.V.M's Shree Damodar College of Commerce \& Economics, College in Margao, Goa, India.(Email: edwin.barreto@rediffmail.com)

Dr.RodneyD'Silva, Associate Professor, Department of Management

V.V.M's Shree Damodar College of Commerce \& Economics, College in Margao, Goa, India.(Email: dsilva.rodney@gmail.com) analytically examines the trends since nationalization in the constituents of earnings and the costs of the same for various clusters of commercial banks in India. Instead of individual banks, the chief focus is on profitability and costs of the banking industry in its entirety.

Karkal (1982) observed the conception of profitability as well as profit, the characteristics that constitute the areas or volume of profit and methods used to plan profit. The study recommended ways to improve bank profitability by improving staff efficiency, raising the difference between lending and borrowing rates and applying standardized maximum service charges. The areas of costs involved in banking services as well as exercises of costing executed within the industry of banking are not covered by this study.

\section{OBJECTIVES}

1. To examine the dynamics of the Indian banking sector.

2. To evaluate and compare financial statement parameters of select private and public sector banks in India.

\section{HYPOTHESIS}

1. H0: There exists no noteworthy difference between IITI Ratio of select private and public sector banks in India.

H1: There exists noteworthy difference between IITI Ratio of select private and public sector banks in India.

2. H0: There exists no noteworthy difference between IETE Ratio of select private and public sector banks in India.

H1: There exists noteworthy difference between IETE Ratio of select private and public sector banks in India.

3. H0: There exists no noteworthy difference between NPM Ratio of select private and public sector banks in India.

H1: There exists noteworthy difference between NPM Ratio of select private and public sector banks in India.

4. H0: There exists no noteworthy difference between ROA Ratio of select private and public sector banks in India.

H1: There exists noteworthy difference between ROA Ratio of select private and public sector banks in India.

5. H0: There exists no noteworthy difference between ROE Ratio of select private and public sector banks in India. 
H1: There exists noteworthy difference between ROE Ratio of select private and public sector banks in India.

6. H0: There exists no noteworthy difference between LD Ratio of select private and public sector banks in India.

H1: There exists noteworthy difference between LD Ratio of select private and public sector banks in India.

7. H0: There exists no noteworthy difference between AD Ratio of select private and public sector banks in India.

H1: There exists noteworthy difference between AD Ratio of select private and public sector banks in India.

\section{RESEARCH METHODOLOGY}

The current research attempts to scrutinize the performance of select private and public sector banks in
India for the period $1^{\text {st }}$ April 2013 to $31^{\text {st }}$ March 2018. For the purpose of the study five public sector banks namely SBI, PNB, BOI, BOB and Canara Bank as well as five private sector banks namely ICICI Bank, HDFC Bank, Yes Bank, Axis Bank and Kotak Mahindra Bank have been considered based on their Net Interest. The performance of banks considered for the study has been analysed using ratio analysis. T-Test has been used to establish the existence of any noteworthy difference between financial ratios of the considered Indian private and public sector banks.

Table 1: Independent Sample T-Test on IITI Ratio

\begin{tabular}{|l|l|l|l|l|l|l|l|l|l|l|}
\hline \multirow{2}{*}{$\begin{array}{l}\text { PARTICULA } \\
\text { RS }\end{array}$} & IITI & IITI & IITI & IITI & IITI & IITI & IITI & IITI & IITI & IITI \\
& Public & Private & Public & Private & Public & Private & Public & Private & Public & Private \\
& Sector & Sector & Sector & Sector & Sector & Sector & Sector & Sector & Sector & Sector \\
Sectio & Sectio & Ratio \\
Ratio & Ratio & Ratio & Ratio & Ratio & Ratio & Ratio & Ratio & Ratio & Ration \\
\hline Mean & 0.90 & 0.80 & 0.90 & 0.78 & 0.89 & 0.80 & 0.84 & 0.77 & 0.85 & 0.77 \\
\hline P- Value & 0.0251 & & 0.0561 & & 0.0111 & & 0.0799 & 0.0729 & \\
\hline
\end{tabular}

\section{Source: Computed Figures}

The Independent Sample T-Test results on IITI Ratio of the select private and public sector banks in India are depicted in Table 1. The mean IITI Ratio of select public sector banks in India is relatively higher than private sector banks for the period of study. Since the p-value is less than the critical value for the years 2014 and 2016, there is enough evidence to reject the null hypothesis which is taken

\section{DATA ANALYSIS}

\& RESULTS

Table 2: Independent Sample T-Test on IETE Ratio

\begin{tabular}{|c|c|c|c|c|c|c|c|c|c|c|}
\hline \multirow{5}{*}{$\begin{array}{c}\text { PARTICULA } \\
\text { RS }\end{array}$} & \multicolumn{2}{|c|}{2014} & \multicolumn{2}{|c|}{2015} & \multicolumn{2}{|c|}{2016} & \multicolumn{2}{|c|}{2017} & \multicolumn{2}{|c|}{2018} \\
\hline & IETE & IETE & IETE & IETE & IETE & IETE & IETE & IETE & IETE & IETE \\
\hline & Public & Private & Public & Privat & Public & Privat & Public & Privat & Public & Private \\
\hline & Sector & Sector & Sector & & Sector & & Sector & & Sector & Sector \\
\hline & Ratio & Ratio & Ratio & $\begin{array}{l}\text { Sector } \\
\text { Ratio }\end{array}$ & Ratio & $\begin{array}{l}\text { Sector } \\
\text { Ratio }\end{array}$ & Ratio & $\begin{array}{l}\text { Sector } \\
\text { Ratio }\end{array}$ & Ratio & Ratio \\
\hline Mean & 0.67 & 0.58 & 0.67 & 0.56 & 0.59 & 0.55 & 0.59 & 0.51 & 0.53 & 0.74 \\
\hline $\mathrm{P}$ - Value & 0.1613 & & 0.1233 & & 0.3425 & & $\begin{array}{l}0.065 \\
7\end{array}$ & & 0.4598 & \\
\hline
\end{tabular}

\section{Source: Computed Figures}

Table 2 depicts the results of Independent Sample T-Test done on IETE Ratio of select Indian private and public sector banks. The mean IETE Ratio of the selected public sector banks in India is relatively higher than private sector banks for the year 2014, 2015, 2016 and 2017. Nevertheless, in the year 2018, the mean IETE Ratio is found to be relatively higher in the case of private sector banks when at five percent significance level. As such it is evident that there exists a noteworthy difference between IITI Ratio of select private and public sector banks in India for the years 2014 and 2016. However in 2015, 2017 and 2018, the pvalue is found to be greater than the critical value leading to acceptance of the null hypothesis indicating that there exists no noteworthy difference between IITI Ratio of select private and public sector banks in India for the particular years. compared to public sector banks. Since the p-value is higher than the critical value for all the years of the study, there is enough evidence for acceptance of the null hypothesis at five percent level of significance. As such there exists no noteworthy difference between IETE Ratio of the selected private and public sector banks in India for the study period. 
Table 3: Independent Sample T-Test on NPM Ratio

\begin{tabular}{|c|c|c|c|c|c|c|c|c|c|c|}
\hline \multirow[b]{2}{*}{$\begin{array}{c}\text { PARTICULA } \\
\text { RS }\end{array}$} & \multicolumn{2}{|c|}{2014} & \multicolumn{2}{|c|}{2015} & \multicolumn{2}{|c|}{2016} & \multicolumn{2}{|c|}{2017} & \multicolumn{2}{|c|}{2018} \\
\hline & $\begin{array}{l}\text { NPM } \\
\text { Public } \\
\text { Sector } \\
\text { Ratio }\end{array}$ & $\begin{array}{l}\text { NPM } \\
\text { Private } \\
\text { Sector } \\
\text { Ratio }\end{array}$ & $\begin{array}{l}\text { NPM } \\
\text { Public } \\
\text { Sector } \\
\text { Ratio }\end{array}$ & $\begin{array}{l}\text { NPM } \\
\text { Private } \\
\text { Sector } \\
\text { Ratio }\end{array}$ & $\begin{array}{l}\text { NPM } \\
\text { Public } \\
\text { Sector } \\
\text { Ratio }\end{array}$ & $\begin{array}{l}\text { NPM } \\
\text { Privat } \\
\text { e } \\
\text { Sector } \\
\text { Ratio }\end{array}$ & $\begin{array}{l}\text { NPM } \\
\text { Public } \\
\text { Sector } \\
\text { Ratio }\end{array}$ & $\begin{array}{l}\text { NPM } \\
\text { Private } \\
\text { Sector } \\
\text { Ratio }\end{array}$ & $\begin{array}{l}\text { NPM } \\
\text { Public } \\
\text { Sector } \\
\text { Ratio }\end{array}$ & $\begin{array}{l}\text { NPM } \\
\text { Privat } \\
\text { e } \\
\text { Sector } \\
\text { Ratio }\end{array}$ \\
\hline Mean & 6.74 & 15.99 & 5.94 & 16.36 & -6.27 & 15.16 & 1.75 & 13.67 & -9.19 & 12.17 \\
\hline $\mathrm{P}-$ Value & 0.0003 & & 0.0264 & & 0.0012 & & 0.0016 & & 0.0037 & \\
\hline
\end{tabular}

\section{Source: Computed Figures}

The Independent Sample T-Test results on NPM Ratio of select Indian private sector and public sector banks are presented in Table 3. The mean NPM Ratio of select private sector banks in India is relatively higher than that of public sector banks for the period of study. Since p-value is less than that of the critical value for all the years of the study, there is enough evidence to accept the alternate hypothesis at five percent significance level indicating the existence of a noteworthy difference between NPM Ratio of select private and public sector banks in India.

Table 4: Independent Sample T-Test on ROA Ratio

\begin{tabular}{|c|c|c|c|c|c|c|c|c|c|c|}
\hline \multirow[b]{2}{*}{$\begin{array}{c}\text { PARTICULA } \\
\text { RS }\end{array}$} & \multicolumn{2}{|c|}{2014} & \multicolumn{2}{|c|}{2015} & \multicolumn{2}{|c|}{2016} & \multicolumn{2}{|c|}{2017} & \multicolumn{2}{|c|}{2018} \\
\hline & $\begin{array}{l}\text { ROA } \\
\text { Public } \\
\text { Sector } \\
\text { Ratio }\end{array}$ & $\begin{array}{l}\text { ROA } \\
\text { Private } \\
\text { Sector } \\
\text { Ratio }\end{array}$ & $\begin{array}{l}\text { ROA } \\
\text { Public } \\
\text { Sector } \\
\text { Ratio }\end{array}$ & $\begin{array}{l}\text { ROA } \\
\text { Private } \\
\text { Sector } \\
\text { Ratio }\end{array}$ & $\begin{array}{l}\text { ROA } \\
\text { Public } \\
\text { Sector } \\
\text { Ratio }\end{array}$ & $\begin{array}{l}\text { ROA } \\
\text { Private } \\
\text { Sector } \\
\text { Ratio }\end{array}$ & $\begin{array}{l}\text { ROA } \\
\text { Public } \\
\text { Sector } \\
\text { Ratio }\end{array}$ & $\begin{array}{l}\text { ROA } \\
\text { Privat } \\
\text { e } \\
\text { Secto } \\
\text { r } \\
\text { Ratio }\end{array}$ & $\begin{array}{l}\text { ROA } \\
\text { Public } \\
\text { Sector } \\
\text { Ratio }\end{array}$ & $\begin{array}{l}\text { ROA } \\
\text { Private } \\
\text { Sector } \\
\text { Ratio }\end{array}$ \\
\hline Mean & 1.92 & 1.70 & 0.46 & 1.72 & -1.78 & 1.51 & 0.14 & 1.39 & -0.75 & 2.51 \\
\hline $\mathrm{P}-$ Value & 0.8835 & & 0.2299 & & 0.1055 & & 0.0020 & & 0.0747 & \\
\hline
\end{tabular}

\section{Source: Computed Figures}

The Independent Sample T-Test results on ROA Ratio of select public sector and private sector banks in India are given in Table 4. The mean ROA Ratio of select private sector banks in India is relatively greater than public sector banks for 2015, 2016, 2017 and 2018. However for the year 2014 the mean ROA Ratio of select public sector banks is relatively higher in comparison to that of private sector banks in India. P-value is more than the critical value for the years 2014, 2015, 2016 and 2018 leading to acceptance of the null hypothesis at five percent level of significance indicating that no noteworthy difference exists between ROA Ratio of select Private and Public Sector Banks in India. However p-value is lower than the critical value for the year 2017 leading to rejection of the null hypothesis at five percent significance level. As such a noteworthy difference is found between ROA Ratio of select private and public sector banks in India in 2017.

Table 5: Independent Sample T-Test on ROE Ratio

\begin{tabular}{|l|l|l|l|l|l|l|l|l|l|l|}
\hline \multirow{2}{*}{\begin{tabular}{c} 
PARTICULA \\
\multicolumn{1}{|c|}{$\mathbf{2 0 1 4}$}
\end{tabular}} & \multicolumn{2}{c|}{$\mathbf{2 0 1 5}$} & \multicolumn{2}{c|}{$\mathbf{2 0 1 6}$} & \multicolumn{2}{c|}{$\mathbf{2 0 1 7}$} & \multicolumn{2}{c|}{2018} \\
\cline { 2 - 10 } & ROE & ROE & ROE & ROE & ROE & ROE & ROE & ROE & ROE & ROE \\
& Public & Private & Public & Private & Public & Private & Public & Private & Public & Private \\
& Sector & Sector & Sector & Sector & Sector & Sector & Sector & Sector & Sector & Sector \\
& Ratio & Ratio & Ratio & Ratio & Ratio & Ratio & Ratio & Ratio & Ratio & Ratio \\
\hline Mean & 8.92 & 16.97 & 7.69 & 15.53 & -9.08 & 14.36 & 1.97 & 12.17 & -13 & 10.38 \\
\hline P- Value & 0.0077 & & 0.0007 & & 0.0041 & & 0.004 & & 0.004 & \\
& & & & & & & 3 & & 2 & \\
\hline
\end{tabular}

\section{Source: Computed Figures}

The Independent Sample T-Test results on ROE Ratio of select private and public sector banks in India is shown in Table 5. The mean ROE Ratio of select private sector banks in India is relatively greater in comparison to public sector banks for the study period. Since p-value is lower than the critical value for the entire period of study, there is enough evidence to reject the null hypothesis at five percent significance level indicating that there exists a noteworthy difference between ROE Ratio of select Private and Public Sector Banks in India. 
Table 6: Independent Sample T-Test on LD Ratio

\begin{tabular}{|l|l|l|l|l|l|l|l|l|l|l|}
\hline \multirow{2}{*}{\begin{tabular}{c} 
PARTICULA \\
\multicolumn{1}{|c|}{$\mathbf{2 0 1 4}$}
\end{tabular}} & \multicolumn{2}{c|}{$\mathbf{2 0 1 5}$} & \multicolumn{2}{c|}{$\mathbf{2 0 1 6}$} & \multicolumn{2}{c|}{$\mathbf{2 0 1 7}$} & \multicolumn{2}{c|}{$\mathbf{2 0 1 8}$} \\
\cline { 2 - 10 } & LD & LD & LD & LD & LD & LD & LD & LD & LD & LD \\
& Public & Private & Public & Private & Public & Private & Public & Private & Public & Private \\
& Sector & Sector & Sector & Sector & Sector & Sector & Sector & Sector & Sector & Sector \\
Mean & Ratio & Ratio & Ratio & Ratio & Ratio & Ratio & Ratio & Ratio & Ratio & Ratio \\
\hline P- Value & 0.77 & 0.93 & 0.75 & 0.96 & 1.99 & 0.80 & 0.69 & 0.95 & 0.70 & 0.96 \\
& 0.1449 & & 0.0498 & & 0.3994 & & 0.000 & & 0.002 & \\
\hline
\end{tabular}

\section{Source: Computed Figures}

The Independent Sample T-Test results on LD Ratio of select public sector and private sector banks in India are depicted in Table 6. The mean LD Ratio of select private sector banks in India is relatively greater in comparison to public sector banks during 2014, 2015, 2017 and 2018. However for the year 2016, mean LD Ratio of select public sector banks are higher when compared to the mean of private sector banks in India. Since p-value is less than the critical value for the years 2015, 2017 and 2018, there is enough evidence to accept the alternate hypothesis at five percent level of significance implying that there exists a noteworthy difference between LD Ratio of the considered private and public sector banks in India for the respective years of study. The $p$-value is greater than the critical value for the years 2014 and 2016 implying that we accept the null hypothesis at five percent level of significance indicating the existence of no noteworthy difference in the LD Ratio of select Indian private and public sector banks.

Table 7: Independent Sample T-Test on AD Ratio

\begin{tabular}{|c|c|c|c|c|c|c|c|c|c|c|}
\hline \multirow[b]{2}{*}{$\begin{array}{c}\text { PARTICULA } \\
\text { RS }\end{array}$} & \multicolumn{2}{|c|}{2014} & \multicolumn{2}{|c|}{2015} & \multicolumn{2}{|c|}{2016} & \multicolumn{2}{|c|}{2017} & \multicolumn{2}{|c|}{2018} \\
\hline & $\begin{array}{l}\text { AD } \\
\text { Public } \\
\text { Sector } \\
\text { Ratio }\end{array}$ & $\begin{array}{l}\mathrm{AD} \\
\text { Private } \\
\text { Sector } \\
\text { Ratio }\end{array}$ & $\begin{array}{l}\text { AD } \\
\text { Public } \\
\text { Sector } \\
\text { Ratio }\end{array}$ & $\begin{array}{l}\mathrm{AD} \\
\text { Private } \\
\text { Sector } \\
\text { Ratio }\end{array}$ & $\begin{array}{l}\text { AD } \\
\text { Public } \\
\text { Sector } \\
\text { Ratio }\end{array}$ & $\begin{array}{l}\mathrm{AD} \\
\text { Private } \\
\text { Sector } \\
\text { Ratio }\end{array}$ & $\begin{array}{l}\text { AD } \\
\text { Public } \\
\text { Sector } \\
\text { Ratio }\end{array}$ & $\begin{array}{l}\text { AD } \\
\text { Private } \\
\text { Sector } \\
\text { Ratio }\end{array}$ & $\begin{array}{l}\text { AD } \\
\text { Publi } \\
\mathrm{c} \\
\text { Secto } \\
\mathrm{r} \\
\text { Ratio }\end{array}$ & $\begin{array}{l}\mathrm{AD} \\
\text { Private } \\
\text { Sector } \\
\text { Ratio }\end{array}$ \\
\hline Mean & 1.21 & 1.58 & 1.20 & 1.61 & 1.21 & 1.55 & 1.20 & 1.54 & 1.21 & 1.55 \\
\hline $\mathrm{P}-$ Value & 0.1025 & & 0.0375 & & 0.0113 & & $\begin{array}{l}0.003 \\
6 \\
\end{array}$ & & $\begin{array}{l}0.004 \\
5 \\
\end{array}$ & \\
\hline
\end{tabular}

\section{Source: Computed Figures}

The Independent Sample T-Test results on AD Ratio of select private and public sector banks in India is shown in Table 7. The mean AD Ratio of select private sector banks in India is relatively higher in comparison to public sector banks for the entire period of study. Since p-value is lower than the critical value for the years 2015, 2016, 2017 and 2018, there exists enough substantiation to accept the alternate hypothesis at five percent significance level indicating the existence of a noteworthy difference between AD Ratio of select Indian private and public sector banks for the respective years of study. Since the p-value is found to be higher in comparison to the critical value for the year 2014, we accept the null hypothesis indicating the absence of a noteworthy difference in the AD Ratio of select Indian private and public sector banks.

\section{FINDINGS AND CONCLUSIONS}

The financial sector holds a critical position in the overall economic progress of a country. There is a general consensus that the banking system is required to be strong and healthy in order to attain sustainable economic growth.
Over the past few years, Indian banks have been experiencing huge challenges in the dynamic settings that they are operating in. Presently the Indian banking sector is well established with regards to its product range, reach and supply. However it needs to break fresh ground for betterment of its overall performance and sustainability.

This study is mainly concerned with scrutinizing the performance of select Indian private and public sector banks between $1^{\text {st }}$ April 2013 and $31^{\text {st }}$ March 2018 endeavouring to reveal the effect of the new dynamic environment on how the banks have performed with respect to the selected parameters.

The following can be inferred from this study:

- The banking sector may have underperformed as a whole and more importantly for the period of the study as the Earnings per Share (EPS) for all ten banks indicates a declining trend.

- The NPM Ratio of public sector banks is relatively lesser than that of private sector banks for the period of study. 
- $\quad$ Performance of public sector banks significantly differed from private sector banks in 2014 w.r.t. IITI Ratio, NPM Ratio and ROE Ratio.

- In 2015, the ROE Ratio, LD Ratio, AD Ratio and NPM Ratio were proved to statistically differ for public and private sector banks.

- $\quad$ The ROE Ratio, AD Ratio, NPM Ratio and IITI Ratio of private sector banks were proved statistically different from public sector banks for the year 2016.

- A significant difference was found between the ROA Ratio, ROE Ratio, LD Ratio, AD Ratio and NPM Ratio of both categories of banks for the year 2017.

- A significant difference was observed in the year 2018 between private and public sector banks w.r.t. ROE, LD Ratio, AD Ratio and NPM Ratio.

\section{REFERENCES}

1. Balaji, C. \& Kumar, G.P. (2016), “A Comparative Study on Financial Performance of Selected Public \& Private Sector Banks in India", Journal of Commerce and Trade, XI (2), pp. 89-96.

2. Banerjee, S. (2012), "Basel I and Basel II Compliance Issues for Banks in India", Macroeconomics and Finance in Emerging Market Economies, 5(2), pp. 228-245.

3. Karkal, C.L. (1982),"Profit and Profitability in Banking", IBA Bulletin, XXIII (3).

4. Mumpilly, P. (1980), "Innovations in Banking- The Indian Experience, Cost and Profitability of Commercial Banking, Development and Economics Department", World Bank, pp. 45-67.

5. Shrivastava, P. \&Rai, K. (2012), "Performance appraisal practices in Indian banks", Integral Review - A Journal of Management, 5 (2), pp. 46-52.

6. Taqi, M \& Mustafa, M.S.M. (2018), "Financial Analysis of Public and Private Sector Banks of India: A Comparative Study of Punjab National Bank and HDFC Bank", International Academic Journal of Business Management, 5(1), pp. 26-47.

\section{ABBREVIATIONS}

IETE: Interest Expense to Total Expense IITI: Interest Income to Total Income NPM: Net Profit Margin

LD: Loan to Deposit AD: Assets to Deposit ROA: Return on Assets ROE: Return on Equity 